\title{
Analysis of Alternative Solution for Improving Voltage Profile Due to Overloading Interconnection System $150 \mathrm{KV}$
}

\author{
Tasma Sucita*, Yadi Mulyadi \\ Department of Electrical Engineering Education \\ Indonesia University of Education \\ Bandung, Indonesia \\ *tasmasucita@upi.edu, yadielektro@upi.edu
}

\begin{abstract}
Voltage profile has a very important role in the distribution of electricity from generation sources to consumers. This research was conducted at PT. PLN APB West Java with the subject of the power flow study conducted to determine the voltage profile, active power flow and loading on the subsystem. The purpose of this study is to determine the voltage profile with a power flow study and understand the concept of operating patterns in a $150 \mathrm{kV}$ transmission system during daily peak load conditions. The reason for this research is to evaluate the extent to which subsystems connected to the looping system can operate without problems that can disrupt the quality and reliability of the network on each busbar. So it is useful in the operation of the electrical system so that the voltage value is still within the reliability criteria of the subsystem. The method in this research explains the study of power flow in a $150 \mathrm{kV}$ electrical system under normal conditions and in the working pattern conditions when the generator is only operating 1 unit, until it does not operate all (0 units) even the entire load is simulated using ETAP Software with analysis method Gauss-Seidel. Research findings with power flow studies are expected to obtain a solution for the system under conditions of low voltage disturbances (under voltage) due to more loading until returning to normal conditions.
\end{abstract}

Keywords-transmission line, load flow, voltage profile, gaussseidel, ETAP power system

\section{INTRODUCTION}

The development of the electricity system in Indonesia continues to increase, from using one machine to many machines (multi-machine). This development is due to the increasing demand for electrical energy, so it is necessary to generate electric energy with a large capacity. To anticipate this, the government has created a program to provide electricity, namely the 35,000-megawatt electricity supply program. As for this program, the power generated by this electrical energy generating system is channelled through an interconnection system.
One of the analyses that can be carried out and the most frequently used in interconnection systems at a steady state is the power flow study [1]. Power flow analysis is the deepest and inseparable part of the study of transmission networks and distribution systems [2]. This system is also very important in planning, developing a system for the future because the good operation of the system depends a lot on knowing the effects of interconnection with other power systems, new loads, new generation substations, and new transmission lines before everything was installed.

Determination or calculation of voltage, current, power, and power factor or reactive power found at various points in an electrical network under normal operating conditions is carried out by means of a power flow study. The result that you want to know from the power flow study is the data that relates the amount of supply power from the generator and the amount of load that requires power under normal operating conditions. This is needed if at any time there is a change in system performance due to accident (interference, lightning strikes, etc.) or intentional (operation, development, etc.). Changes in system performance due to changes in the generator, transmission, or load can be analysed if the amount of voltage, current, and power flowing in the network is known and this is where a power flow study is needed.

Various methods of completing power flow studies have been increasingly developed in line with the development of the power system network system, both in planning, development, and the environment. The algorithm in this study is new but classic. The data input of the algorithm is the data orientation of the regular branch bus. Until now, several methods that are often studied are the Gauss-Seidel Method, the Newton Raphson Method, the Decoupled Method, and the Fast Decoupled Method [3]. This method applies the Taylor series to obtain a derivative of the mathematical equation as a basis for iteration calculations using the Jacobian matrix [4], [5].

Research conducted at State Electricity Company in West Java Area is a power flow study to determine the voltage 
profile, active power, and loading on the subsystem. By evaluating these parameters, we can measure the extent to which the subsystem connected to the looping system can operate without any disturbance to the quality and reliability of the network on each busbar. In solving the problem of this study, the author uses the Gauss-Seidel power flow calculation method assisted by ETAP software version 12.6.0 to simulate the power flow in the subsystem connected to the $150 \mathrm{kV}$ electrical system. In this study, several parameters of the findings of the study will be shown.

\section{METHODOLOGY}

\section{A. Research Design}

This research is a quantitative study, namely to determine how much voltage, current, active power, and reactive power that flows in the electric power system in the Cibatu IBT 3-4 and Mandirancan transmission subsystems. The method used in analyzing these quantities is the Gauss-Seidel method which is integrated into the ETAP version 12.6.0 program.

Based on data obtained from PT. PLN (Persero) West Java Load Management Area (APB) in 2017, the Cibatu IBT 3 - 4, and Mandirancan subsystems are supplied by the Indramayu Steam Power Plant (PLTU) with a ratio of 7: 3. In the Cibatu IBT 3-4 subsystem, there is a Jatiluhur hydropower plant and in the Mandirancan subsystem, there is a CEP PLTU.

In this research, a work pattern trial will be carried out to maintain the reliability and availability of power in the Cibatu IBT 3 - 4 and Mandirancan subsystems when PLTU Indramayu is in operation for 1 unit or in a state, not all-in operation (0 units). As for the simulation process, it will be known the conditions on each bus that experience voltage drops due to disturbances that occur due to overload (trip) in the system.

\section{B. Method of Analysis}

1) Bus admittance matrix: Preparation of the $Y_{\text {bus }}$ matrix in completion of the power flow study. To obtain the nodevoltage equations with the impedance value expressed in perunit base MVA, the soil value is ignored in terms of calculation. The voltage gain is based on Kirchoff's current law, where the impedance is converted into a quantity of admittance with the following equation [6]:

$$
y_{i j}=\frac{1}{z_{i j}}=\frac{1}{V_{i j}+j X_{i j i}}
$$

2) Gauss-seidel method power flow: The power flow equation is usually written in terms of the bus admittance matrix elements. Since then the diagonal-off element of the $Y_{\text {bus }}$ bus admittance matrix, shown by the equation above, namely $Y_{i j}=-y_{i j}$, and the diagonal element is $Y_{i i}=\Sigma y_{i j}$, the equation becomes [7]:

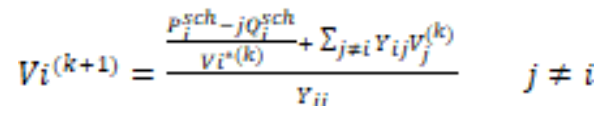

and

$$
\begin{aligned}
& P_{\mathrm{i}}^{(k+1)}=\Re\left\{V_{i}^{(k))}\left[V_{i}^{(k)} Y_{\mathrm{ii}}+\sum_{\substack{j=1 \\
i \neq 1}}^{n} Y_{\mathrm{i} j} V_{j}^{(k)}\right]\right\} j \neq 1 \\
& Q_{i}^{(k+1)}=-\mathfrak{S}\left\{V_{i}^{*(k)}\left[V_{i}^{(k)} Y_{i i}+\sum_{\substack{j=1 \\
j \neq 1}}^{n} Y_{i j} V_{j}^{(k)}\right]\right\} j \neq 1 \\
& \mathrm{~V}=\text { voltage } \\
& \mathrm{Y}=\text { phase angle } \\
& \mathrm{P}=\text { active power } \\
& \mathrm{Q}=\text { reactive power }
\end{aligned}
$$

\section{Flow Chart}

The stages in this research include: determining research objectives, collecting the theoretical basis of research, determining research procedures, conducting tests, and analyzing test results. The research stages are structured so that the research can run systematically, from the research stages above then a research flow chart is compiled as shown in Figure 1.

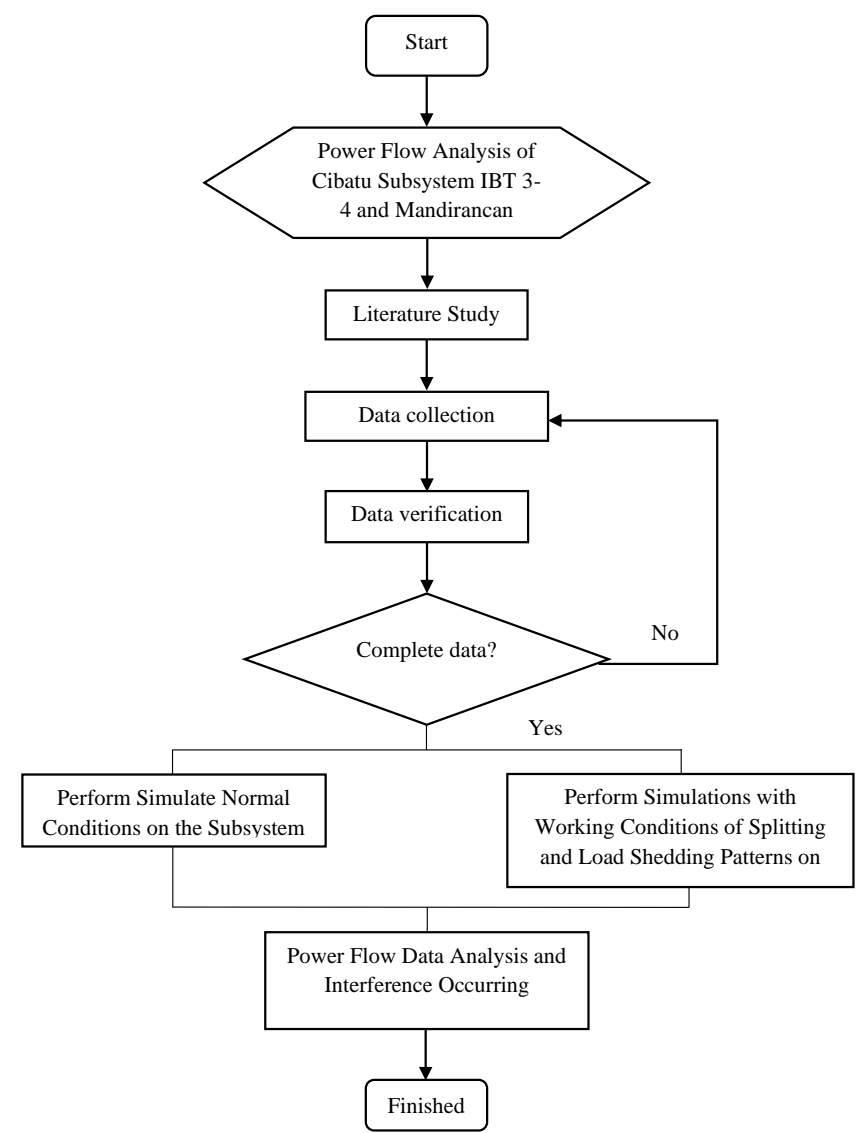

Fig. 1. Stages of the research flow. 


\section{RESULTS AND DISCUSSION}

\section{A. Result of Research}

The results of data analysis obtained are in the form of data regarding the conductors used, data regarding the power output of the generator, loading data, and power flow contained in the $150 \mathrm{kV}$ transmission line in Cibatu IBT 3 - 4 and Mandirancan subsystems. The following is the conducting data used on the $150 \mathrm{kV}$ transmission line in the Cibatu IBT 3 - 4 and Mandirancan subsystems. Figure 2 shows the results of the peak load of the Cibatu Subsystem IBT 3 - 4 at night of 1015.25 MW and the results of the peak load of the Mandirancan Subsystem at night of 595.66 MW.

In the $150 \mathrm{kV}$ transmission line system Cibatu IBT 3 - 4 and Mandirancan subsystems, there are several generators that supply power for needs. The power generated by the power plant from the results of daily reports at PT. West Java PLN APB is shown in Tables I and II. The loading data on the 150 $\mathrm{kV}$ system Cibatu IBT $3-4$ and Mandirancan Subsystems obtained from the analysis are shown in Table III.

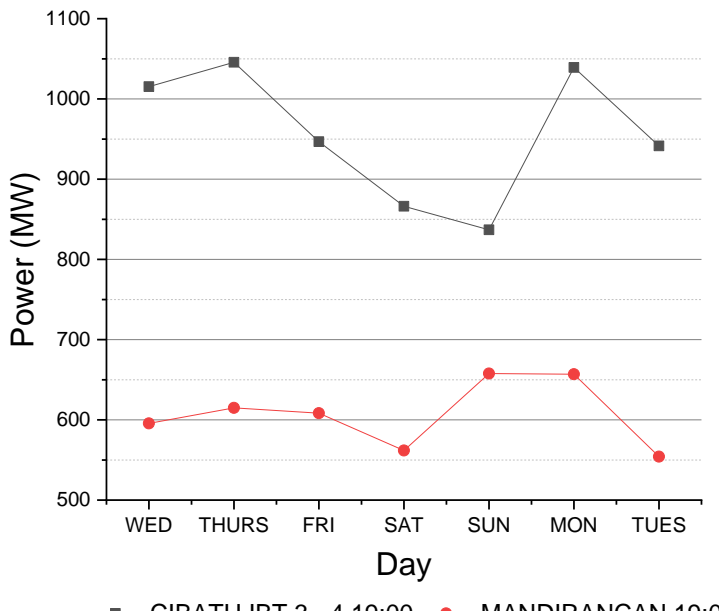

Fig. 2. First week peak load graph

TABLE I. GENERATOR INPUT POWER

\begin{tabular}{|l|l|l|}
\hline \multirow{2}{*}{\multicolumn{1}{c|}{ Power Plants }} & \multicolumn{2}{c|}{ Rating } \\
\cline { 2 - 3 } & \multicolumn{2}{c|}{ MVA } \\
\hline PLTA JATILUHUR 1 & 35 & 6,3 \\
\hline PLTA JATILUHUR 2 & 35 & 6,3 \\
\hline PLTA JATILUHUR 3 & 35 & 6,3 \\
\hline PLTA JATILUHUR 4 & 35 & 6,3 \\
\hline PLTA JATILUHUR 5 & 35 & 6,3 \\
\hline PLTA JATILUHUR 6 & 40 & 6,3 \\
\hline PLTU INDRAMAYU 1 & 388 & 24 \\
\hline PLTU INDRAMAYU 2 & 388 & 24 \\
\hline PLTU INDRAMAYU 3 & 388 & 24 \\
\hline PLTU KANCI & 817,6 & 23 \\
\hline
\end{tabular}

TABLE II. GENERATOR OUTPUT POWER

\begin{tabular}{|l|c|c|}
\hline \multirow{2}{*}{ Power Plants } & \multicolumn{2}{|c|}{ Rating } \\
\cline { 2 - 3 } & $\boldsymbol{P}(\boldsymbol{M W})$ & $\boldsymbol{Q}$ (Mvar) \\
\hline PLTA JATILUHUR 1 & 42,55 & 0 \\
\hline PLTA JATILUHUR 2 & 42,55 & 0 \\
\hline PLTA JATILUHUR 3 & 18,61 & 0 \\
\hline PLTA JATILUHUR 4 & 0 & 0 \\
\hline PLTA JATILUHUR 5 & 0 & 0 \\
\hline PLTA JATILUHUR 6 & 0 & 10,66 \\
\hline PLTU INDRAMAYU 1 & 48,26 & $-1,07$ \\
\hline PLTU INDRAMAYU 2 & $-2,59$ & 26,03 \\
\hline PLTU INDRAMAYU 3 & 164,86 & 3,8 \\
\hline PLTU KANCI & 239,27 & \\
\hline
\end{tabular}

TABLE III. LOADING ON $150 \mathrm{KV}$ SYSTEM CIBATU IBT 3-4 AND MANDARICAN SUBSYSTEM

\begin{tabular}{|l|c|c|}
\hline \multirow{2}{*}{ Subsystem } & \multicolumn{2}{|c|}{ Rating } \\
\cline { 2 - 3 } & $\boldsymbol{P}(\boldsymbol{M W})$ & $\boldsymbol{Q}($ Mvar $)$ \\
\hline Cibatu IBT 3 - 4 & 1131,13 & 108,23 \\
\hline Mandirancan & 785,84 & 203,34 \\
\hline
\end{tabular}

\section{B. Reading of Rail Voltage Profiles in Cibatu Subsystem} Simulation IBT 3 - 4 and Mandirancan Normal Conditions

Rail tension profile recorded by PT. PLN is a voltage profile that is read directly by the SCADA system (Supervisory, Control, and Data Acquisition), while the rail voltage profile on ETAP 12.6.0 is obtained from the GaussSeidel power flow simulation results. The maximum iteration is 1000 iterations, while the precision is 0.0001 with the resulting power flow as shown in the Figure 3.

The overall tension profile of the rail on the Cibatu IBT 3-4 and Mandirancan $150 \mathrm{kV}$ subsystems before changes to the system such as the determination of the splitting point in ETAP 12.6.0. The voltage profile reading appears when the power flow simulation has been successfully executed. The result of the stress profile reading is shown in Figure 3.

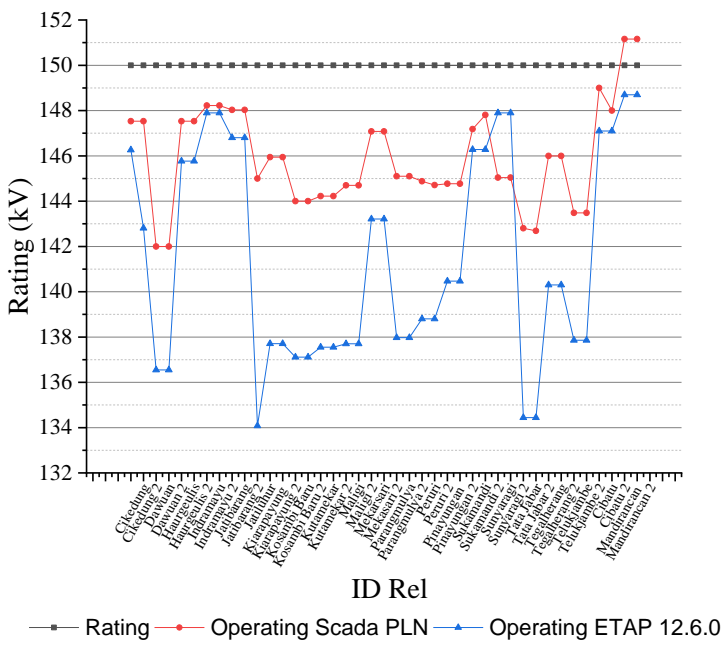

Fig. 3. Voltage profile graph by PT . PLN and ETAP 12.6.0. 


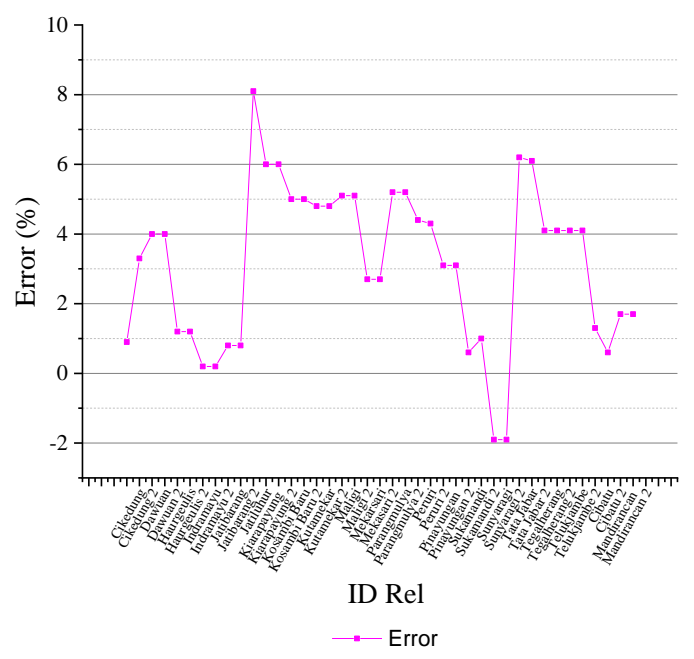

Fig. 4. Precentage of voltage profile error.

The smallest voltage profile read by the PT SCADA system. PLN is the Dawuan and Dawuan 2 rail with a voltage profile of $142 \mathrm{kV}$ or $87.5 \%$ of the voltage rating of $150 \mathrm{kV}$ and the largest voltage profile read is the Mandirancan and Mandirancan 2 rails with a voltage profile of $151.16 \mathrm{kV}$ or $98.48 \%$ of the rated voltage $150 \mathrm{kV}$, while the smallest voltage profile read on the ETAP 12.6.0 is found on the Jatiluhur rail at $134.08 \mathrm{kV}$ or $89.4 \%$ of the $150 \mathrm{kV}$ rated voltage and the largest voltage profile read on the Mandirancan I and II rails is 148.70 $\mathrm{kV}$ or $99.16 \%$ of the rated voltage of $150 \mathrm{kV}$. The voltage profile graph is shown in the Figure 3 and the percentage error profile of the voltage is shown in the Figure 4.

\section{Load Channels in Cibatu Subsystem Simulation IBT 3 - 4 and Mandirancan Normal Conditions}

In this condition, it can be seen that the IBT load on the Cibatu IBT 3 - 4 and Mandirancan subsystems is still within the safe limit or has exceeded the IBT capacity limit. The operation of the generator, as it is known, will affect the amount of IBT load, besides that IBT needs to also pay attention to the capacity of the conductor and the voltage at each substation. If the simulation results cause the possibility of blackout due to the above factors, then a further simulation will be carried out by splitting at certain locations. This aims to maintain the reliability of the system itself.

The amount of system bus voltage when there is no (normal) disturbance is at least $134.08 \mathrm{kV}$ on the Jatiluhur load bus and the greatest voltage is $148.70 \mathrm{kV}$ on the Mandirancan I and II buses. On Figure 3 shows that the system voltage at peak load conditions is below the SPLN standard. There are 8 rails that meet the SPLN standards, namely the Cik Gedung rail $(146.26 \mathrm{kV})$, Jatibarang-Jatibarang $2(146.80 \mathrm{kV})$, HaurgeulisHaurgeulis $2(145.77 \mathrm{kV})$ Indramayu-Indramayu 2 (147.90 $\mathrm{kV})$, Sukamandi-Sukamandi $2(146.28 \mathrm{kV})$, SunyaragiSunyaragi $2(147.90 \mathrm{kV})$, Cibatu-Cibatu $2(147.10 \mathrm{kV})$ and Mandirancan-Mandirancan $2(148.70 \mathrm{kV})$.

\section{Simulation of Load Shedding in Cibatu IBT 3-4 and Mandirancan Subsystems}

Figure 3 shows how the state of the voltage value in the Cibatu IBT 3 - 4 and Mandirancan subsystems, there are still several channels whose voltage values are less than the rating allowed by PLN. With the results of the data in Figure 3, a load shedding scenario is carried out.

The load shedding in this scenario is carried out in two stages using real simulation data. Because during normal conditions, the measured voltage in the ETAP 12.6.0 program shows a critical voltage or is below the value allowed by PLN. Table IV shows the planned load shedding scheme.

The IBT 3 Cibatu loading graph shown in Figure 5 explains that during normal conditions IBT 3 Cibatu the cargo charge was $666,076 \mathrm{MW}$, when there was a disturbance at IBT 3 Cibatuebanan it decreased to 651,893 . Then followed by the disturbance at PLTU Indramayu which caused a loading of more than $676,905 \mathrm{MW}$ so that load shedding was required.

TABLE IV. LOADING SHEDDING SCHEME

\begin{tabular}{|c|c|c|c|c|}
\hline Stage & Substation & V & Load & MW \\
\hline \multirow{2}{*}{ Stage 1 } & PRMYA & 150 & KTMKR & 10,95 \\
& PRMYA & 150 & MLIGI & 15,42 \\
\hline & & & Tranformer-1 & 11 \\
& & Tranformer-2 & 23 \\
Stage 2 & \multirow{3}{*}{ MKSRI } & PNYGN 1-2 & 55 \\
& & & Tranformer-1 & 25 \\
& & TLJBE 1-2 & 85,64 \\
& & Tranformer-2 & 20,38 \\
\hline \multicolumn{3}{|c|}{ Total OLS } & 246,39 \\
\hline \multicolumn{3}{|c|}{ Difference } & 419,686 \\
\hline
\end{tabular}

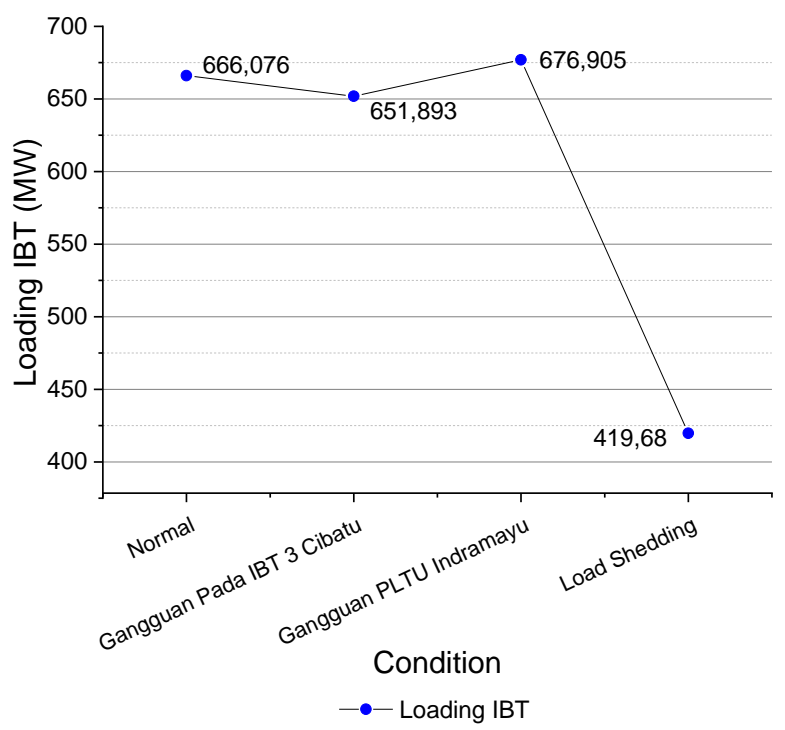

Fig. 5. Load shedding scenarios. 


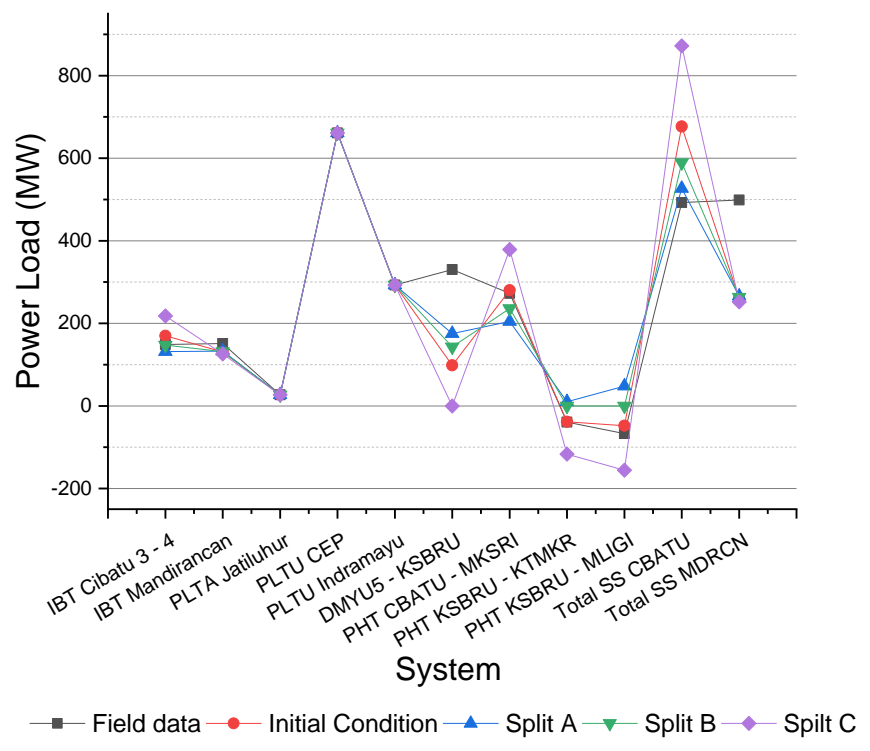

Fig. 6. Comparison graph of existing loads and simulation results.

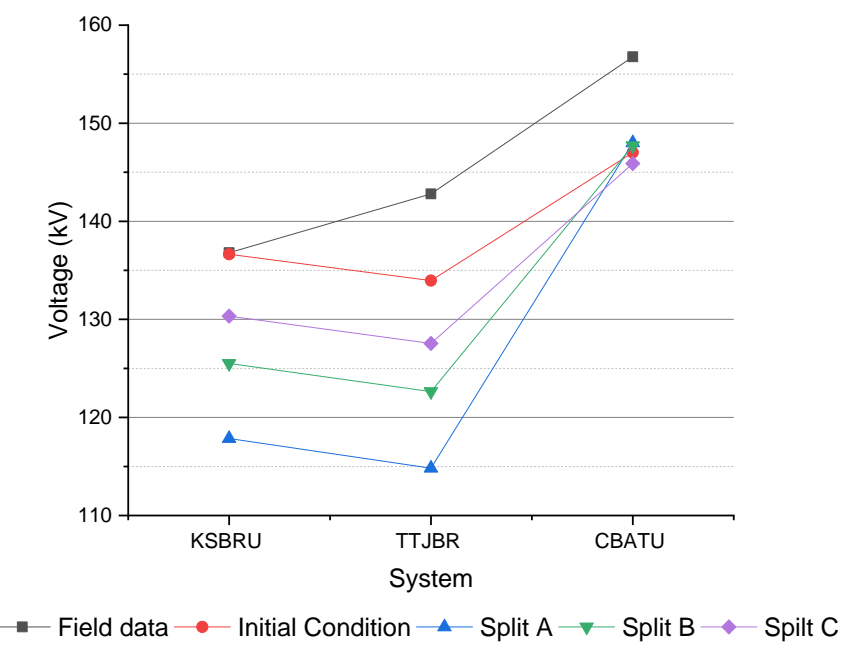

Fig. 7. Comparison of field and simulation voltage values.

\section{E. Results of Field Data and ETAP Software Simulation Data}

1) Simulation of Cibatu 3 - 4 and Mandirancan subsystem operation patterns in the condition of PLTU Indramayu 1 unit operation: In this simulation, it is seen that the IBT load on the Cibatu IBT 3 - 4 and Mandirancan subsystems is still within the safe limit or has exceeded the IBT capability limit. The simulation will be carried out at PLTU Indramayu if it operates 1 unit at night. Figure 5 shows the splitting results of several simulations, such as the split A open PMT PHT MLIGI and KTMKR simulation conditions on the PRMYA substation, in the split B open PMT PHT MLIGI and KTMKR simulation conditions on the KSBRU substation and the last on the split C open PMT IPM simulation conditions. IDMYU 1 - 2 GI KSBRU.

Based on some of the cases above, if the PLTA Indramayu operates 1 unit at night, the looping configuration between Cibatu 3 - 4 and Mandirancan subsystems is chosen, it can be said to be the same as the initial conditions. Even though in the initial conditions the looping voltage is still out of the allowable range for $150 \mathrm{kV}$, and at the time of split $\mathrm{C}$ the voltage increases but becomes no better because of the excursion voltage.

2) Simulation of Cibatu 3 - 4 and Mandirancan subsystem operation patterns in the condition of PLTU Indramayu operation 0 units: The simulation will be carried out at PLTU Indramayu if it operates 1 unit at night and PLTU Indramayu if it operates 0 units or does not operate at all. Table 4.14 will show the splitting results of several simulations, such as in the simulation conditions of split A open PMT PHT MLIGI and KTMKR on the KSBRU substation and split B openPMT PHT MLIGI and KTMKR on the KSBRU substation, DWUAN substation.

In the initial conditions, the PLTU Indramayu environment is simulated when all of them are not operated ( 0 units). The maximum load value of the Cibatu IBT subsystem 3 - 4 supplies the Mandirancan subsystem, in the initial conditions with PLTU Indramayu operating 0 units of 216,788 MW and $182,794 \mathrm{MW}$. 4. The value of the voltage on the conductor that passes through the load in the initial conditions with PLTU Indramayu operating 0 units of $131.38 \mathrm{kV}$ on the KSBRU channel, $128.61 \mathrm{kV}$ on the TTJBR channel, and on the 146.07 $\mathrm{kV}$ CBATU channel.

\section{CONCLUSION}

The maximum load value of the Cibatu IBT subsystem 3 4 supplies the Mandirancan subsystem, the initial conditions for PLTU Indramayu to operate 1 unit are 169.80 MW and 130.82 MW and at 0 units are 216.788 MW and 182.794 MW. The value of the voltage quality on the conductor that is passed through the load, the initial condition of PLTU Indramayu operates 1 unit of $136.64 \mathrm{kV}$ on the KSBRU channel, 133.96 $\mathrm{kV}$ on the TTJBR channel, and on the CBATU channel 147.01 $\mathrm{kV}$ and at 0 units it is $131.38 \mathrm{kV}$ in KSBRU channels, 128.61 $\mathrm{kV}$ on TTJBR channels and on CBATU 146.07 kV channels. According to a study on the splitting operation pattern of PLTU Indramayu operating 1 unit, the right location when the Cibatu subsystem is unable to withstand a large load to supply the Mandirancan subsystem is in the split C pattern, namely by opening PMT PHT IDMYU 1 - 2 at the KSBRU substation while if it operates 0 units is with a spill A pattern, namely by opening the PMT PHT MLIGI and KTMKR at the KSBRU substation. 


\section{REFERENCES}

[1] R. Sreerama Kumar and E. Chandrasekharan, "A parallel distributed computing framework for Newton-Raphson load flow analysis of large interconnected power systems," Int. J. Electr. Power Energy Syst., vol. 73, pp. 1-6, 2015, doi: 10.1016/j.ijepes.2015.03.020.

[2] N. Mehnaz, A. I. Bhuiyan, M. Roy, and F. Hossain, "Load flow analysis and abnormality removal of bangladesh power system using software CYME PSAF," Proc. - Int. Conf. Intell. Syst. Model. Simulation, ISMS, pp. 384-388, 2013, doi: 10.1109/ISMS.2013.88.

[3] M.R. Hossain, M.S. Kaiser, F.I. Ali, and M.M.A. Rizvi, "Network flow optimization by Genetic Algorithm and load flow analysis by Newton Raphson method in power system," 2nd Int. Conf. Electr. Eng. Inf.
Commun. Technol. iCEEiCT 2015, no. December 2016, 2015, doi: 10.1109/ICEEICT.2015.7307388

[4] T. . Phan, V. . Nguyen, M.J. Hossain, A.N. To, and H.T. Tran, "An unified iterative algorithm for load flow analysis of power system including wind farms," Proc. - 2016 Int. Conf. Adv. Comput. Appl. ACOMP 2016, pp. 105-112, 2017, doi: 10.1109/ACOMP.2016.024.

[5] Emmy Hosea and Yusak Tanoto, "Perbandingan Analisa Aliran Daya dengan Menggunakan Metode Algoritma Genetika dan Metode Newton-Raphson," J. Tek. Elektro, vol. 4, no. 2, pp. 63-69, 2004.

[6] F. Jusmedy, "Studi Aliran Daya Sistem 115 kV PT. Chevron Pacific Indonesia," Universitas Sumatera Utara, 2007.

[7] D. Sulistiyino, "Perbandingan metode gauss - seidel, metode newton raphson dan metode fast decoupled dalam solusi aliran daya," Makal. Tugas Akhir, 2011. 